American Journal of Educational Research and Reviews
(ISSN:2474-9265)

\title{
Here We Go Again: An Analysis of Re-Segregation in Georgia Charter Schools
}

\author{
Andrea N. Smith, Ed.D. \\ University of West Georgia, College of Education, Early Childhood Through Secondary Education
}

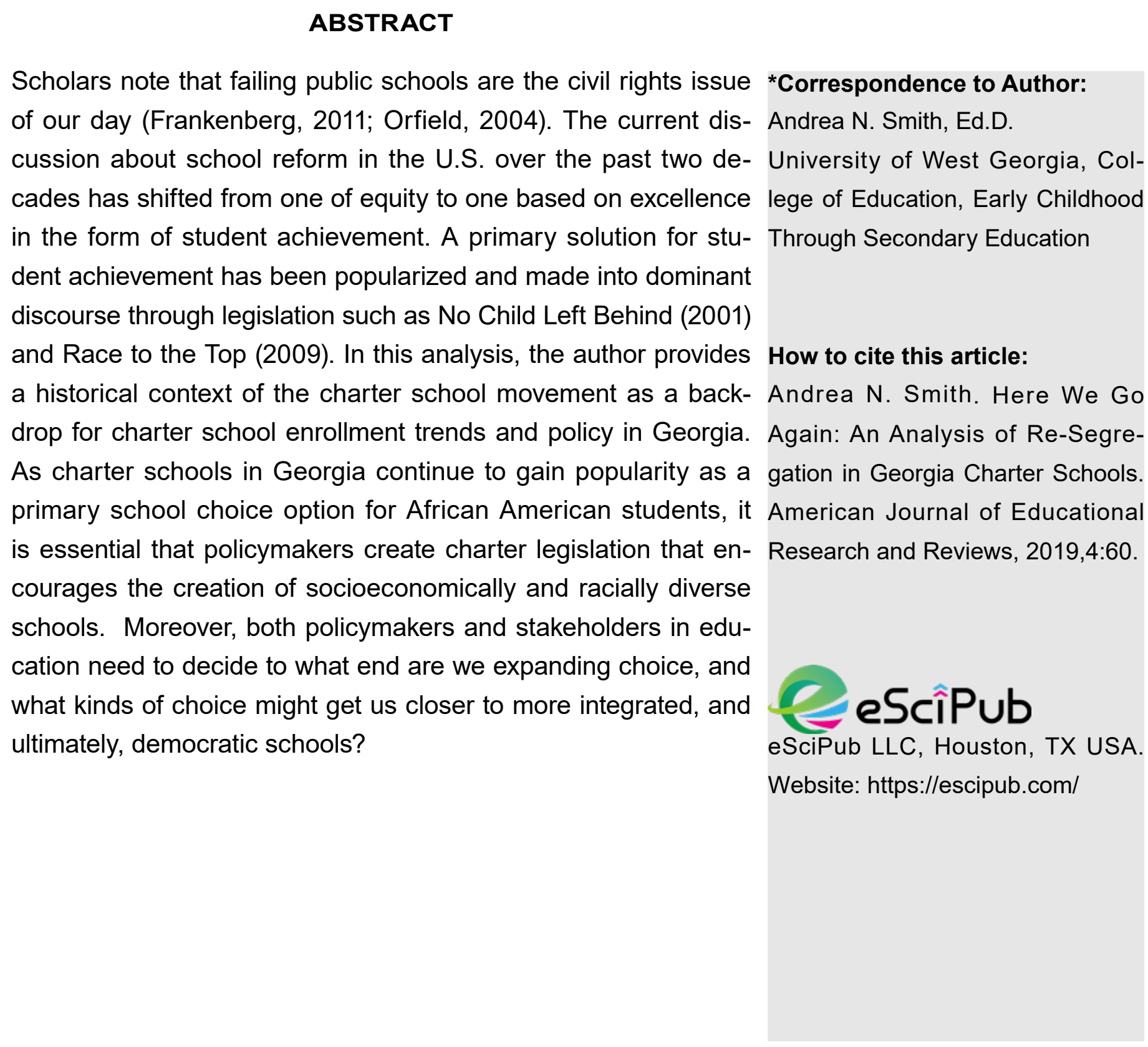




\section{Introduction}

Since the conception of education in the U.S., schools have been the battlegrounds for equal opportunities among African American students. Laws such as Brown v. Board of Education (1954) provided an avenue through which African American students could attend integrated public schools in an effort to ensure equality. Although research notes the benefits of providing more students with integrated school environments is a cost-effective strategy for boosting student achievement and preparing students for work in a diverse global economy (Mickelson, 2008), more than 70 percent of black students attend segregated schools with a majority black peer population today (Clotfelter, 2004).

A shift from equity that values diversity to a focus on excellence in the form of student achievement has resulted in limited discussion on policy development aimed to enhance racial composition of schools and ultimately student achievement. Once such primary solution for student achievement has been popularized and made into dominant discourse through legislation such as No Child Left Behind (2001) and Race to the Top (2009). Both pieces of legislation posit market choices in education as a means to solve underachievement of students; particularly students of color.

Researchers add that parental choice becomes a method that is entangled in an already inequitable school system in which practices and policies are historically linked to race and class (Frankenberg, Siegel-Hawley, and Wang, 2011). While most agree that the issue deserves attention, consensus dissolves around how to respond to the problem. Given the salience of such issues as racial segregation, public debate about expanding charter schools is everincreasing. The Georgia Department of Education (2014) defines a charter school as "a public school of choice that operates under the terms of a charter, or contract, with an authorizer, such as the state and local boards of education." Advocates of charter schools not only point to the expansion of educational options for minority and low-income students; but the forced competition between charters and traditional publics schools that they note will enhance education for the common good of all students. Critics, however, argue that these reforms have led to increased segregation by race and class as more motivated families move to better schools, leaving the most disadvantaged students behind in the worst public schools. In other words, while charter schools are meant to provide diverse educational opportunities for minority students, they have more often than not led to greater stratification and separation of students by race and ethnicity across schools in our nation.

As growing concerns about charter school segregation have accelerated, sixteen states have put regulations in place that require or encourage charter schools to take positive action to ensure diversity (Eckes, S.E., \& Trotter, A. E., 2007). For example, states such as Connecticut require charter schools to recruit from all segments of the district. In South Carolina, the racial composition of charter schools is required not to differ by more than $20 \%$ from that of the local school district (The law, § 59-40-70(D). Unfortunately, studies in states with such regulations commonly report that the regulations are being ignored or not enforced (Institute on Race and Poverty, 2008).

\section{A Shift from Integration to Choice}

The Brown decision in 1954 marked what was to be heralded in education as the end of racial segregation in schools. Since that time, countless federal and district policies outlined expectations such as busing and district and rezoning to ensure racial diversity in schools. However, the era when courts were willing to force integration through mandatory busing ended in the mid-1990's as more schooling options for parents were making its way on the education scene.

Since the adoption of the first charter school in Minnesota in 1991, charter schools have received considerate attention from policy 
makers, educators, parents, and the media. The charter school movement has had bipartisan support including the support of three consecutive presidents: Bill Clinton, George W. Bush, and Barack Obama. In the Obama administration, charter schools have been stressed under the "Race to the Top" fund of the American Recovery Act of 2009 and the regulations of the School Recovery and Investment Act of 2009 (Nagel, 2009). Yet, Moe (2003) declares, "School choice has provoked more political conflict than any other reform..." (p. 60).

Some view charter schools as a welcome addition to the public school sector, while others doubt the benefit of these schools. Supporters hope that charter schools will be able to cut through red tape and offer innovative and effective educational programs, provide new options to families (especially low-income and minority families), and promote healthy competition for traditional public schools (Kolderie, 2004 and Nathan, 1998). Opponents argue that charter schools are no more effective than traditional public schools, that they may exacerbate racial segregation, that they create fiscal strains for school districts, and that too many of them are fly-by-night movements that fall between vouchers and magnet schools as choice.

\section{Charters School Segregation}

Many studies conclude that charter schools intensify racial and economic segregation (Center for Urban and Multicultural Education, 2010). Researchers from UCLA's Civil Rights Project (Frankenberg et al., 2010) report that at the national level, all groups of minority students attending charter schools were likely to experience more segregation in charter schools. They found that 70 percent of Black charter school students attended racially isolated minority charter schools (schools with 90-100 percent of students from under-represented minority backgrounds), compared to only 36 percent of Black students in traditional public schools. The researchers conclude: "Ironically, charter schools held an early promise of becoming more integrated than regular public schools because they were not constrained by racially isolating school district boundary lines (p. 23)." This report shows instead that charter schools make up a separate, segregated sector of our already deeply stratified public school system. Studies in a number of different states and school districts in the U.S. show that charter schools often lead to increased school segregation (Bifulco \& Ladd, 2007; Booker, Zimmer, \& Buddin, 2005; Cobb \& Glass, 2003; Clotfelter, Ladd, \& Vigdor, 2013; Frankenberg, Siegel-Hawley, \& Wang, 2011). Based on descriptive statistics on enrollment patterns of charter schools in 40 states including the District of Columbia based on federal data, the authors posit that charter schools have become highly segregated and often cater to low-income and minority student populations. This, according to the authors, is still an unrealized dream of the Brown decision.

Despite all the research concerning charter schools, Frankenberg, E., Siegel-Hawley, G., \& Wang, J. (2011) utilize an interesting perspective by analyzing access to charters and racial isolation at a time when racial diversity is supposed to be prevalent in societal institutions. The authors' focus on race in the article allows researchers to use critical race theory as an analytic tool for better understanding inequities in education and factors that contribute to the Black-White achievement gap. The article further adds to the literature on inequities in education and provides policymakers with methods to reduce segregation such as new legislation that requires charters to collect better data on diverse groups of students to vary student enrollment patterns and their outcomes, as well as to better promote and create magnet schools. Conversely, much of the literature on student achievement in the article is mixed due to limited compliance of charters to supply specific data on subgroups of students both racially and language-based. Interestingly, in the region where charter schools were first created, 
Miron (2005) elaborates on the intensification of racial and economic segregation in the Twin Cities schools. A geographical analysis shows that the racial makeups of charter schools mimic the racial composition of the neighborhoods where they are located. This contrasts sharply with the claim that charter schools would sever the link between segregated neighborhoods and schools.

Although various studies (Rothstein, 2004; Orfield \& Lee, 2004) note the harmful effects of segregation particularly on high minority population schools, existing research on the effects of social composition suffers from a number of conceptual and empirical shortcomings (Jencks \& Mayer, 1990; Schofield, 1995). First, some studies do not investigate the effects of different compositional characteristics such as race, SES, and academic background on student outcomes. Also, few studies investigate the effects of social composition are able to identify what explains those effects. As Jencks and Mayer (1990) pointed out in their review, "Almost all of it relies on a 'black box' model of neighborhood and school effects that makes no assumptions about how social composition influences individual behavior" ( $p$. 115).

The studies reviewed further use a mix of methodologies both quantitative and qualitative, so as to highlight the reasons behind segregated enrollment patterns and the economic and academic impact on students. Some compared the demographic characteristics of students in school choice programs with those in the traditional public schools they would have attended. Others compared the characteristics of students in school choice programs with those in the surrounding communities. Case studies were also conducted to increase understanding of the reasons for the choices families and schools make. Regardless of the specific methodology used, however, the preponderance of research evidence points to a strong link between school choice programs and an increase in student segregation by race, ethnicity, and income, segregation as a direct reflection of the design of the school choice program.

Ritter et al. (2010) critiques the UCLA-based Civil Rights Project (CRP) study "Choice without Equity: Charter School Segregation and the Need for Civil Rights Standards." The authors' analysis of charter school patterns of resegregation pinpoint the segregation not as a charter phenomenon because the geographic placement of charter schools practically ensures that they will enroll higher percentages of minorities and because serving disadvantaged populations is the stated mission of many charter schools, they seek out locations near disadvantaged populations intentionally. So, the conclusion by conservative, free-market advocates who generally back charter schools is that charters can't be blamed if they happen to end up drawing particular populations of students. Instead, this is a reflection of active parental choices rather than the forced segregation of our nation's past. On the contrary, this Ritter et al.'s (2010) conclusion overlooks three invariable truths about the nature of "choice" in America and its relationship to race. Foremost, there are geographic patterns of racial segregation in America is a condition inherited by our nation's racist past and, in fact, a condition we've yet to successfully address through housing policy or other means. Second, the way parents exercise "choice" is often reflective of not just what they want their kids to study and how they want them to be taught but also of what other kind of children they want their kids to be around. Lastly, the playing field that "choice" operates on is often anything but even. Charters generally by their very nature are exempt from many of the requirements of traditional public schools, including providing transportation and food, having adequate facilities and specialists for children with developmental problems, and providing for students who don't speak English as their first language. 
As many charter schools continue to enroll high populations of African American students, a number of researchers have attempted to determine the root cause for the re-segregation in these schools. Historically, the federal government supported integration as a primary tool for ensuring equality within and between schools. Over time, however, the focus of education reform has shifted from one of integration to equity and equal resources to students regardless of hyper-segregation of schools in the United States. So, where does that leave the case for integration in Georgia charter schools today?

\section{A Look at Georgia}

In 1993 the Georgia General Assembly enacted legislation creating charter schools in Georgia for the first time. Public charter school legislation was officially passed in Georgia on April 19, 1993, which created the legal basis for the beginning of the Georgia charter school movement. The Charter Schools Act of 1998, located in Title 20 of Georgia Code, is the law that governs Georgia charter schools today. The legislative intent of the act is "to increase student achievement through academic and organizational innovation by encouraging local school systems to utilize the flexibility of a performance based contract called a charter" (Charter Schools Act of 1998, 20-2-2062).

\section{Charter School Enrollment Trends}

Since the creation of charter school legislation in Georgia, the number of charter schools in the state has grown steadily (Georgia Department of Education, 2017). In particular, the number of charter schools doubled in 2008-2009 as a result of legislation such as House Bill 797, Act No. 766 provided for a diverse range of charter schools (both start-up and conversion), to expand in great numbers; many of whom target minority populations. As of 2012, Georgia had 217 charter schools serving 56 school districts (Charter Schools Division Annual Report, 2012). This brought charter school enrollment to $7.7 \%$ of the total student population enrolled in public schools within Georgia in 2013. Consequently, the racial and ethnic composition of such schools has become more intensified as start-up charter schools and recent legislation allowing multiple authorizers to approve charters, has changed the school choice landscape. While all charter schools serve almost the same percent of White students as statewide $38.5 \%$ to $38.9 \%)$, currently all charter schools serve more Black students $(46.5 \%$ to $36.4 \%)$ and fewer Hispanic students (9.0\% to $16.3 \%)$ than the state (Georgia Department of Education, 2017).

\section{Charter School Enrollment Policy}

Georgia's public schools, both traditional and charter, utilize Title VI of the Civil Rights Act of 1964 to safeguard against discrimination on the basis of race, color or national origin (Georgia Department of Education, 2014). This federal law outlines how all public schools are to act in accordance with federal guidelines that ensure equity.

Currently, Georgia's enrollment policy provides that charter schools must be open to any student residing in the district or covered in an interdistrict agreement. Georgia law requires charter schools to admit students via a random selection process when the number of applications exceeds the capacity of a program, class, grade level, or building (National Alliance for Public Charter Schools, 2014). However, there are no federal or state policies that mandate school diversity.

For the most part, diversity is only addressed in Georgia by requiring charter schools to hold an equitable selection process, such as a lottery, in an effort to determine who will be enrolled if more students apply than there are openings at the school (Georgia Department of Education, 2014). Even under the lottery system, however, this process can have both intended and unintended consequences that increase racial segregation. For one, they limit the services they provide, thereby excluding certain students, or offer programs that appeal only to a limited group of families (Furgeson et al., 2012). Also, charter schools choose where to locate which, in turn, effects enrollment options given the 
transportation difficulties for low-income students (Gulosino \& d'Entremont, 2011). he racial and ethnic composition of Georgia charter schools is different than of the state.

McCluaghlin (1990) notes that federal initiatives assume a direct relationship between federal policy 'inputs,' local responses, and program 'outputs,' as can be seen in diversity initiatives at the school level in charter schools. School enrollment policies, while synonymous with federal policies, lack federal and state legislative push to ensure diversity. For example, many start-up charter schools in Georgia tend to align their enrollment policies with federal and state guidelines that often focus on providing additional resources to schools that have high minority and/or low-income populations (Kahlenberg \& Potter, 2012). As a result, such schools tend to target mainly low-income and/or minority students. In essence, the prioritization of resources for minority and/ or low-income students has provided a fertile ground for charter schools in Georgia and the nation to neglect racial diversity.

\section{Policy Recommendations}

A surge of states have modified the charter school authorization process in response to federal support for charter schools under recent laws such as Race to the Top (2009). Consequently, consideration for the impact on racial and economic isolation of students is often left unaddressed. It is evident that segregation and inequality still divide our society along the lines of race and class, and educational literature documents the myriad ways in which school choice may exacerbate this stratification (Orfield, 2001). Fortunately, studies also show integration and choice can coexist successfully with certain structures in place to mitigate the divisive effects of choice (Schofield, 2005). While education policymakers cannot directly influence the composition of schools in the private sector, shape housing policy, or influence the increasing changes in demographic populations, they can restructure existing choice plans and new ones that create opportunities for diversity. Recommendations for policymakers and other stakeholders include the following:

\section{Restructure existing choice policies to ensure diversity.}

- Because unregulated school choice leads to de facto segregation by race, SES, and at times by achievement, return to controlled-choice admission plans based on combinations of residential census tracts, student achievement, and SES (Frankenberg, E., Siegel-Hawley, G., \& Wang, J., 2011).

- State funding policies that are meant to provide more funds for students seen as more difficult to educate provide charter school providers with incentives to open charter schools that cater to certain demographics of students (Frankenberg, E., Siegel-Hawley, G., \& Wang, J., 2011).

\section{Increase and Enforce Accountability.}

- Ensure that all charter schools are held to the same accountability standards as traditional public schools.

\section{Provide improved information to parents about charter school options.}

- Provide better information to parents about the importance of diverse schools and the benefits that such schools provide all students (Schofield, 2001).

\section{Conclusion}

All in all, market policies are not egalitarian in nature. Choice theorists believe that charter schools can serve to provide options for diversity to African American students who have historically been stuck in 'failing schools.' In contrast, opponents view charter schools in stark contrast to their intended purpose. In theory, charter schools are blind to race and SES which completely conflicts with charter school advocates' argument that such schools promote diversity. However, because most charters are designed to serve a homogeneous 
population, the very nature of the design of the program permits schools to segregate.

Coined as a "civil rights" issue (Frankenberg, 2011), charters have grown out of the undergirding theory that providing minority and low-income students with additional school choice options to their 'failing' traditional schools will enhance the academic achievement. Even more so, the literature reveals that most charter schools are highly segregated and serve mostly African American students throughout the country (Fuller et al., 2003). The issue of segregation, however, is further complicated by lack of federal incentives and oversight of charter schools in addition to de facto segregation housing patterns that impact the states around the nation.

In Georgia, enrollment data of charter schools mirrors that of national data. Federal incentives for states that become charter friendly have opened the door for the creation of many charter schools in the Georgia and other states. For example, Georgia allows multiple charter school authorizers to aid in charter school approval (National Alliance for Public Charter Schools, 2014).

While charter schools have been highlighted for their role in increasing racial segregation, some school choice programs do have a positive effect on integration. A small proportion of charter schools are designed specifically to increase diversity (Kahlenberg \& Potter, 2012). In addition, magnet school programs, which were originally started to increase integration, have often succeeded in doing so. However, like other school choice programs, magnet schools tend to segregate when diversity is no longer a specific goal (Siegel-Hawley \& Frankenberg, 2011).

It is going to take a major shift in how society views diversity and integration. The 1960's highlighted the importance that the public placed on integration and equality. However, as decades have passed, the discourse that overshadowed equality and promoted achievement and outcomes. So, diversity it seems is no longer viewed as essential to the education experiences of students.

As charter schools in Georgia continue to gain popularity as a primary school choice option for African American students, it is essential that policymakers create charter legislation that encourages the creation of socioeconomically and racially diverse schools. Moreover, both policymakers and stakeholders in education need to decide to what end are we expanding choice, and what kinds of choice might get us closer to more integrated, and ultimately, democratic schools?

\section{References}

1. Armor, D. J. (1983). The Evidence on Desegregation and Black Achievement.

2. Bifulco, R. \& Ladd, H.F. (2007). School choice, racial segregation, and test-score gaps: Evidence from North Carolina's charter school program. Journal of Policy Analysis and Management, 26, 31-56.

3. Brown-Jeffy, S. (2006). The race gap in high school reading achievement: Why school racial composition still matters. Race, Gender \& Class, 268-294.

4. Center for Urban and Multicultural Education. (2010). Charter Schools Research Brief. Indiana University School of Education, Indianapolis, IN. Retrieved from http://education.iupui.edu/cume/pdf/charterschoo Isbrieffinal.pdf

5. Clotfelter, C.T., Ladd, H.F., \& Vigdor, J.L. (2013). Racial and economic diversity in North Carolina's schools: An update. Durham, NC: Duke Sanford School of Public Policy.

6. Cobb, C.D. \& Glass, G.V. (2003). Arizona charter schools: Resegregating public education? Chicago, IL: American Educational Research Association

7. Center for Research on Educational Outcomes (CREDO) (2009). Multiple Choice: Charter School Performance in 16 States. Retrieved April 12, 2014 from http://credo.stanford.edu/reports/MULTIPLE_CH OICE_CREDO.pdf

8. Eckes, S.E., \& Trotter, A. E. (2007). Are charter schools using recruitment strategies to increase student body diversity? Education and Urban Society, 40(1), 62-90. 
9. Frankenberg, E., Siegel-Hawley, G., \& Wang, J. (2011). Choice without equity: Charter school segregation. Education Policy Analysis Archives, 19 (1). http://epaa.asu.edu/ojs/article/view/779

10. Frankenberg, E. (2011) Charter Schools: A Civil Rights Mirage? Kappa Delta Pi Record, 47 (3): 100-105.

11. Fuller, B. (2003). Education policy under cultural pluralism. Educational Researcher, 32(9), 15-24.

12. Furgeson, J., Gill, B., Haimson, J., Killewald, A., McCullough, M., Nichols-Barrer, I., Lake, R. (2012). Charter school management organizations: Diverse strategies and diverse student impacts (Updated ed.). Princeton, NJ: Mathematica Policy Research.

13. Georgia Department of Education (2014). Charter School Basics. Retrieved from http://www.gadoe.org/external-affairs-andpolicy/charter-schools/pages/general-frequentlyasked-questions.aspx

14. Georgia Department of Education (2017). 2018 Charter Schools Annual Report. Retrieved from https://www.gadoe.org/External-Affairs-andPolicy/Charter-

Schools/Committee\%20Members/2018\%20Chart er\%20Schools\%20Annual\%20Report.pdf

15. Gulosino, C. \& d'Entremont, C. (2011). Circles of influence: An analysis of charter school location and racial patterns at varying demographic scales. Education Policy Analysis Archives, 19 (8). Retrieved from http://epaa.asu.edu/ojs/article/view/842

16. Herchinger, J. (2011, December. 22). Segregated Charter Schools Evoke Separate but Equal Era in the U.S. Retrieved from http://www.bloomberg.com/news/2011-1222/segregated-charter-schools-evoke-separatebut-equal-era-in-u-s-education.html

17. Institute on Race and Poverty. (2008). Failed promises: Assessing charter schools in the Twin Cities. Minneapolis: Author, University of Minnesota Law School. Retrieved from http://www.irpumn.org/uls/resources/projects/2_C harter_Report_Final.pdf

18. Jencks, C., \& Mayer, S. E. (1990). The social consequences of growing up in a poor neighborhood. In L. Lynn Jr. \& M. G. H. McGeary (Eds.), Inner-city poverty in the United States (pp. 111186). Washington, DC: National Academy Press.

19. Lewis, C. W., James, M., Hancock, S., \& HillJackson, V. (2008). Framing African American Students' Success and Failure in Urban Settings A Typology for Change. Urban Education, 43(2), 127-153.
20. Lubienski, C. \& Weitzel, P. (2009). Choice, integration, and educational opportunity: Evidence on competitive incentives for student sorting in charter schools. Journal of Gender, Race, \& Justice, 11, 351-376.

21. Mahard, R. E., \& Crain, R. L. (1983). Research on minority achievement in desegregated schools. The consequences of school desegregation, 103125.

22. R. A. Mickelson. (2008) "Twenty-first Century Social Science Research on School Diversity and Educational Outcomes," Ohio State Law Journal 69:1173-228.

23. Miron, G., Urschel, J.L., Mathis, W.J., \& Tornquist, E. (2010). Schools without diversity: Education management organizations, charter schools and the demographic stratification of the American school system. Boulder, CO \& Tempe, AZ: Education and the Public Interest Center \& Education Policy Research Unit.

24. National Alliance for Public Charter Schools. (2014). Measuring up. Retrieved from http://www.publiccharters.org/get-the-facts/lawdatabase/

25. Orfield, G. and Lee, C. (2004). Brown at 50: King's dream or Plessy's nightmare? Cambridge, MA: The Civil Rights Project at Harvard University.

26. Orfield, G., \& Lee, C. (2005). Why segregation matters: Poverty and educational inequality. Civil Rights Project at Harvard University (The).

27. Ritter, G., Jensen, N., Kisida, B., \& McGee, J. (2010). A Closer Look at Charter Schools and Segregation: Flawed Comparisons Lead to Overstated Conclusions. Education Next, 10(3), 69-73.

28. Rothstein, R. (2004). Class and schools: Using social, economic, and educational reform to close the achievement gap. Washington, DC: Economic Policy Institute.

29. Rushing, W. (2001). Inequality and education reform: Formulating a macro-historical sociology perspective. Race, Ethnicity and Education, 4, 2944.

30. Schofield, J. W. (1995). Review of research on school desegregation's impact on elementary and secondary students. In J. A. Banks (Ed.), Handbook of research on multicultural education (pp. 597-616). New York: Macmillan.

31. Siegel-Hawley, G. \& Frankenberg, E. (2011). Does law influence charter school diversity? An analysis of federal and state legislation. Michigan Journal of Race \& Law, 16, 321-376. 
Andrea N. Smith, AJERR, 2019; 4:60

32. The law, $\S 59-40-70(D)$, includes a provision that allows charter school outside this range to continue operating if a monitoring board finds that the school enrolls students in a nondiscriminatory manner.

33. U.S. Department of Education. (2009). Race to the Top program executive summary. Washington, DC: Author. www2.ed.gov/programs/ racetothetop/executivesummary.pdf 